\title{
Management Compensation And Project Life
}

Charles I. Harter, (E-mail: charles.harter@ndsu.nodak.edu), North Dakota State University

T. Harikumar, New Mexico State University

\begin{abstract}
The goal of this paper is to empirically examine the relation between management compensation and project life. Prior theoretical research suggests that short-term compensation, in the form of bonus plans, have a tendency to induce managers to invest in projects with short lives. Initially, we develop a model that relates management compensation, earnings announcement and project life defined in terms of duration. Our testable hypothesis states that a greater weight placed on short-term compensation induces managers to invest in projects with shorter duration and is reflected in a lower earnings response coefficient (ERC) for a concurrent earnings announcement. We empirically examine whether there is a relation between type of managerial compensation and ERC. After controlling for the firm's investment opportunity set and other variables known to affect the ERC, we find strong evidence indicating a negative relation between project life and the fraction of short-term compensation in the total compensation package. This result provides evidence that managers with greater proportionate earnings-based compensation tend to invest in shorter-term projects.
\end{abstract}

\section{Hypothesis}

Researchers in the past suggest that short-term compensation may induce managers to accept shorter-term projects thereby resulting in corporate myopia (Hayes \& Abernathy (1980), Woolridge (1993), and Narayanan (1985). This paper provides an empirical test to determine if a higher proportionate short-term compensation induces managers to invest in shorter-term projects. We conduct this test using the earnings response coefficient as a proxy for project duration. A derivation and proof that ERC is a proxy for project life is available from the authors. See Table 1 for a summary of ERC research.

We postulate that ceteris paribus, higher proportionate short-term compensation is associated with a lower $E R C$ on the earnings announcement date.

Table 1:

Prior Research on the ERC and persistence of earnings innovations.

- Miller \& Rock (1985) - Present model showing that the market reaction to earnings announcements (ERC) is a function of the persistence of earnings innovations.

- $\quad$ Kormendi \& Lipe (1987) - Empirical test of Miller \& Rock. They show that ERC is positively correlated with persistence, using an ARIMA model to proxy persistence.

- $\quad$ Easton \& Zmijewski (1989) - Empirical test of ERC. They show that ERC is a function of persistence (ARIMA), risk (Beta), and investment opportunity set (market value to book value of equity).

- $\quad$ Harikumar \& Harter (1995) - Empirical test to show that Tobin's Q is a proxy for the investment opportunity set.

- Subramanyam \& Wild (1996) - Empirical test of relation between ERC and firm life. Show statistically significant inverse relation between firm's probability of termination and ERC. 


\section{Empirical Model}

We test our hypothesis using a sample obtained from the 1987 Forbes 800 firms with compensation data on salary, bonus, stock rights, stock ownership and compensation from exercise of options. ${ }^{1}$ Each firm included in our sample was required to have all the relevant data on the COMPUSAT, CRSP, and IBES tapes. Our final sample consists of 251 firms. In order to mitigate the measurement problems associated with the estimation of unexpected earnings, we employ reverse regressions and examine the 'Return Response Coefficient' (RRC) instead of ERC. ${ }^{2}$ This approach reduces measurement error by placing the noisiest variable on the left-hand side of the regression equation.

We investigate the impact of short-term compensation on $R R C$ after controlling for persistence and size of the firm. As presented in Table 1, Collins and Kothari (1989) show that firms with higher market to book value of equity ratios (firms with growth opportunities) tend to have greater persistence in earnings, thereby resulting in a higher ERC. Harikumar and Harter (1995) use the Miller and Rock (1985) model and show that Tobin's $q$ serves as a proxy for persistence and significantly affects the ERC. They also show that the correlation between Tobin's $q$ and the ratio market to book value of equity is about 0.80 and therefore the ratio market to book value of equity serves as a proxy for persistence. Hence, we include the ratio of market to book value of equity as an independent variable in our test. If size is a proxy for differences in informationalenvironment, then different sized firms will exhibit different $E R C$ 's [Collins, Kothari and Rayburn (1987)]. In order to control for such differences in the informational environment, we use the natural logarithm of assets as an independent variable controlling for the size of the firm.

We go one step further comparing the relation between ERC and management compensation for a sample of firms with primarily short-term compensation to a sample of firms with primarily long-term compensation. The results are presented below.

\section{Results}

Table 2 presents the summary characteristics of our sample. The median short-term compensation as a fraction of total compensation is $57.79 \%$. Thus, our sample is not materially biased toward either short-term or long-term (stock-based) compensation. The median value of market to book value of equity is 2.1534. A high median value suggests that the sample of firms in our study have profitable growth opportunities that may affect the $E R C$. The correlation matrix in Panel B reveals some interesting results. The percent of compensation in terms of salary and bonus $(E C)$ is significantly negatively correlated with market to book value of equity $(M B)$ indicating that managers of firms with greater investment opportunities tend to be compensated with proportionately more stockbased compensation. ${ }^{3}$ There is also significant positive correlation between $E C$ and SIZE and a significant negative correlation between $M B$ and SIZE.

\section{Earnings-based compensation and project life}

Our hypothesis states that, ceteris paribus, there is a negative relation between the proportion of short-term compensation and project life. Earnings innovations arising from investments with shorter lives, by definition, do not persist. This suggests that the $R R C$ for firms with managers compensated with proportionately more earningsbased compensation will be higher than the $R R C$ for firms with managers compensated with proportionately more stock-based compensation.

\footnotetext{
${ }^{1}$ These are firms that appear in any of the four lists, made by Forbes magazine in 1987, as measured by sales, total assets, market value of equity or profits. [See Agrawal and Knoeber (1996) for a recent use of this data source.]

${ }^{2}$ See Collins and Kothari (1989), Maddala (1977) and Beaver, Lambert, and Ryan (1987) for a discussion on reverse regressions and return response coefficients.

${ }^{3}$ See Lewellen, Loderer, and Martin (1987) for a discussion on the relation between growth opportunities and earnings/stock-based compensation.
} 
Table 2:

This table provides the overall characteristics of our sample.

\begin{tabular}{|c|c|c|c|c|}
\hline \multicolumn{5}{|c|}{ Panel A: Summary statistics } \\
\hline Variable & $\mathrm{N}$ & Mean & Median & Standard Deviation \\
\hline UES & 251 & 0.0023 & 0.0000 & 0.0473 \\
\hline XRET & 251 & 0.0041 & 0.0023 & 0.0348 \\
\hline $\mathrm{EC}$ & 251 & 0.5442 & 0.5779 & 0.2763 \\
\hline MB & 251 & 2.1534 & 1.7711 & 2.1534 \\
\hline SIZE & 251 & 7.9402 & 7.8346 & 1.0715 \\
\hline
\end{tabular}

Panel B: Correlation matrix

$\begin{array}{llll} & \text { EC } & \text { MB } & \text { SIZE } \\ \text { EC } & 1.0000 & & \\ \text { MB } & -0.3675 * * * & 1.0000 & \\ \text { SIZE } & 0.1453 * * & -0.2776 * * * & 1.0000\end{array}$

\begin{tabular}{lll}
\hline Notes & & \\
UES & & Standardized unexpected earnings \\
XRET $=$ & Excess returns around the earnings announcement date \\
EC $=$ & Proportion of short-term compensation (in terms of salary and bonus) to total compensation \\
MB $=$ & Market to book value of equity \\
SIZE $=$ & Log (Assets) \\
$*$ & & Significant at $10 \%$. \\
$* *$ & Significant at $5 \%$. \\
$* * *$ & & Significant at $1 \%$.
\end{tabular}

Table 3 presents the results from our Model. The adjusted $\mathrm{R}^{2}$ is 0.1015 . The F-statistic for the regression is significant at 1 percent. The coefficient on $E C$ is 1.1809 and is statistically significant at the 1 percent level. This result supports our hypothesis that higher proportion of the earnings-based compensation is associated with a higher $R R C$ or a lower $E R C$. As $E R C$ is a proxy for project life, we find that short-term compensation results in managers taking shorter-term projects. We also find a negative relation between market to book value of equity and $R R C$. While this is consistent with the results reported in the literature [Harikumar and Harter (1995)], the coefficient is statistically significant only at the $10 \%$ level. We do not find a statistically significant result for the SIZE variable.

The results of our test comparing firms with long-term compensation to firms with short-term compensation is presented in Table 4 . The adjusted $\mathrm{R}^{2}$ is higher at 0.1041 .

The F-statistic for the regression is significant at the $1 \%$ level. The coefficient on the dummy interaction variable is highly significant at the $1 \%$ level. This indicates that the $R R C$ for the set of firms with higher than median values of $E C$ is significantly greater than that for firms with lower than median values of $E C$. Since there is an inverse relation between $R R C$ and $E R C$, we find that firms with higher than median values of $E C$ are associated with a lower $E R C$. As $E R C$ is a proxy for project life, we conclude that the evidence in Table 4 strongly supports our hypothesis that short-term compensation induces managers to take on shorter term projects. The other variables in the regression are not statistically significant, although the signs of the coefficients are as hypothesized.

Firms with profitable investment opportunities have high Tobin's $q$-ratios, and firms with unprofitable investment opportunities have low $q$ ratios. We compute $q$ as market value of equity plus book value of debt divided by the book value of assets. This renders the $q$ ratio as a more accurate measure of the 'quality' of the firm's current and future investment opportunities. Lang and Litzenberger (1989) demonstrate that an average $q$ ratio greater than unity is a necessary condition for a firm to be at the value-maximizing level of investment. In thiscontext, we examined the relation between ERC and short-term compensation for two sub-samples, one 
consisting of firms with $q$ ratio less than the median of 1.78 and the other consisting of firms with $q$ ratio greater than 1.78. We hypothesize that the low $q$ sub-sample ought to reveal a stronger (positive) negative relation between $R R C(E R C)$ and proportionate short-term compensation. ${ }^{4}$

Table 3:

This regression introduces the variables for earnings based compensation, market to book value of equity and the size of the firm. Values in parenthesis denote t-statistics.

Model : $U E S_{i}=b_{0}+b_{1} X R E T_{i}+b_{2}\left(E C_{i}^{*} X R E T_{i}\right)+b_{3}\left(M B_{i} * X R E T_{i}\right)+b_{4}\left(S_{Z I Z E_{i}}^{*} X R E T_{i}\right)+e_{i}$

\begin{tabular}{|c|c|c|c|}
\hline \multicolumn{3}{|c|}{ Variable } & Results \\
\hline \multicolumn{3}{|c|}{ Intercept } & $\begin{array}{l}0.0012 \\
(0.4180)\end{array}$ \\
\hline \multicolumn{3}{|l|}{ XRET } & $\begin{array}{l}0.6185 \\
(0.8470)\end{array}$ \\
\hline \multicolumn{3}{|c|}{ EC*XRET } & $\begin{array}{l}1.1809 \\
(3.7040) * * *\end{array}$ \\
\hline \multicolumn{3}{|c|}{ MB*XRET } & $\begin{array}{l}-0.1044 \\
(-1.6680)^{*}\end{array}$ \\
\hline \multicolumn{3}{|c|}{ SIZE*XRET } & $\begin{array}{l}-0.0904 \\
(-0.9370)\end{array}$ \\
\hline \multicolumn{2}{|l|}{$\mathrm{F}$} & & $8.061 * * *$ \\
\hline \multicolumn{2}{|l|}{$\mathrm{R}^{2}$} & & 0.1159 \\
\hline \multicolumn{2}{|c|}{ Adj. $R^{2}$} & & 0.1015 \\
\hline \multicolumn{2}{|l|}{$\mathrm{N}$} & & 251 \\
\hline \multicolumn{4}{|l|}{ Notes } \\
\hline UES & $=$ & \multicolumn{2}{|l|}{ Standardized unexpected earnings } \\
\hline XRET & $=$ & \multicolumn{2}{|c|}{ Excess returns around the earnings announcement date } \\
\hline & $=$ & \multicolumn{2}{|c|}{$\begin{array}{l}\text { Proportion of short-term compensation (in terms of salary and bonus) } \\
\text { to total compensation }\end{array}$} \\
\hline & $=$ & \multicolumn{2}{|c|}{ Market to book value of equity } \\
\hline SIZE & $=$ & \multicolumn{2}{|l|}{ Log (Assets) } \\
\hline & \multicolumn{2}{|l|}{ Significant at $10 \%$, } \\
\hline$* *$ & & \multicolumn{2}{|l|}{ Significant at $5 \%$, } \\
\hline & \multicolumn{2}{|l|}{ Significant at $1 \%$. } \\
\hline
\end{tabular}

The results are presented in Table 5. Panel A contains results for the low $q$ sub-sample. The benchmark model reveals a significant announcement effect. Model 1 indicates that there is a statistically significant positive relation (at the 1\% level) between $R R C$ and proportionate short-term compensation. This also implies that there is a significant negative relation between $E R C$ and proportionate short-term compensation. This is consistent with our hypothesis. The results for model 2 in the case of the high $q$ sub-sample are presented in Table 5, Panel B. We find that there is no statistically significant relation between $E R C$ and proportionate short-term compensation. ${ }^{5}$ This result suggests that there is a stronger relation between short-term compensation and tendency to select projects with shorter lives among firms with a low $q$. This result, however, must be read with caution as the benchmark model in Panel B does not reveal a significant announcement effect. The results from Model 3 are qualitatively similar.

\footnotetext{
${ }^{4}$ We also conduct a similar test using the $M B$ ratio to stratify the sample. The results were qualitatively the same and hence not reported here.

${ }^{5}$ This result must be read with caution as the benchmark model does not reveal a significant announcement effect for this sub-sample.
} 
Table 4:

This regression introduces the variables for earnings based compensation, market to book value of equity and the size of the firm. The dummy variable on the compensation variable takes on a value of 1 if $E C>$ median $E C$ of 0.58 , else it is equal to 0 . Values in parenthesis denote t-statistics.

Model : $U E S_{i}=b_{0}+b_{1} X R E T_{i}+b_{2} \operatorname{Dum}^{*}\left(E C_{i} * X R E T_{i}\right)+b_{3}\left(M B_{i} * X R E T_{i}\right)+b_{4}\left(\operatorname{SIZE}_{i} * X R E T_{i}\right)+e_{i}$

\begin{tabular}{ll}
\hline Variable & Model 2 \\
\hline & \\
Intercept & 0.0014 \\
XRET & $(0.4900)$ \\
& 0.5216 \\
Dum*EC*XRET & $(0.719)$ \\
MB*XRET & 0.9081 \\
SIZE*XRET & $(3.8040)^{* * *}$ \\
& -0.0812 \\
$\mathrm{~F}$ & $(-1.2660)$ \\
$\mathrm{R}^{2}$ & -0.0472 \\
Adj. $\mathrm{R}^{2}$ & $(-0.5110)$ \\
$\mathrm{N}$ & $8.263 * * *$ \\
& 0.1184 \\
$\mathrm{~N}$ & 0.1041 \\
\hline
\end{tabular}

\begin{tabular}{lll}
\hline Notes & & \\
UES $=$ & Standardized unexpected earnings \\
XRET $=$ & Excess returns around the earnings announcement date \\
Dum $=$ & Dummy variable (Dum) $=1$ if EC $>0.58$ (median EC), else Dum $=0$. \\
EC $=$ & $\begin{array}{l}\text { Proportion of short-term compensation (in terms of salary and bonus) } \\
\text { to total compensation }\end{array}$ \\
MB $=$ & Market to book value of equity \\
SIZE $=$ & Log (Assets) \\
$*$ & & Significant at $10 \%$, \\
$* *$ & & Significant at $5 \%$, \\
$* * *$ & & Significant at $1 \%$.
\end{tabular}

\section{Implications}

Our results suggest that managers compensated primarily with salary and bonuses focus their attention on short term profitability. Managers receiving stock compensation show more concern for the long-run profitability of the firm. This result suggests that stockholders benefit when firms offer stock options or some other form of stock compensation to managers when those managers have an opportunity to decide among projects to invest firm resources.

Recently the press has suggested that some managers receive such a large number of stock options that they may be over compensated. For example, a manager receiving 1 million options earns $\$ 1$ million dollars if the stock price increases one dollar. This large number of options may impact the incentive affect derived from stock option compensation. In this paper we found an inverse relation between the proportion of short-term to long-term compensation and project life. Our methodology did not consider the actual dollar amounts of compensation. Future research is needed to determine if there are diminishing to long-term compensation. 
Table 5 :

This table presents the results for all the models in the context of sub-samples stratified on the basis of the full sample median Tobin's $q$ of 1.78. Values in parenthesis denote t-statistics.

Panel A: Sample of firms with $q<1.78$

\begin{tabular}{llll}
\hline Variable & Benchmark & Model 1 & Model 2 \\
\hline Intercept & 0.0002 & 0.0026 & 0.0026 \\
& $(0.0300)$ & $(0.4660)$ & $(0.4580)$ \\
XRET & 0.5291 & -0.4295 & 0.1800 \\
& $(3.0820) * * *$ & $(-0.2640)$ & $(0.1120)$ \\
EC*XRET & - & 2.2128 & - \\
Dum*EC*XRET & - & $(3.2600) * * *$ & 1.3098 \\
SIZE*XRET & & - & $(2.963) * * *$ \\
F & - & -0.0537 & -0.0399 \\
$\mathrm{R}^{2}$ & & $(-0.2710)$ & $(-0.2000)$ \\
Adj. R & & $6.944 * * * 280 * * *$ \\
$\mathrm{~N}$ & $9.500 * * *$ & 0.1469 & 0.1347 \\
\hline
\end{tabular}

Panel B: Sample of firms with $q>1.78$

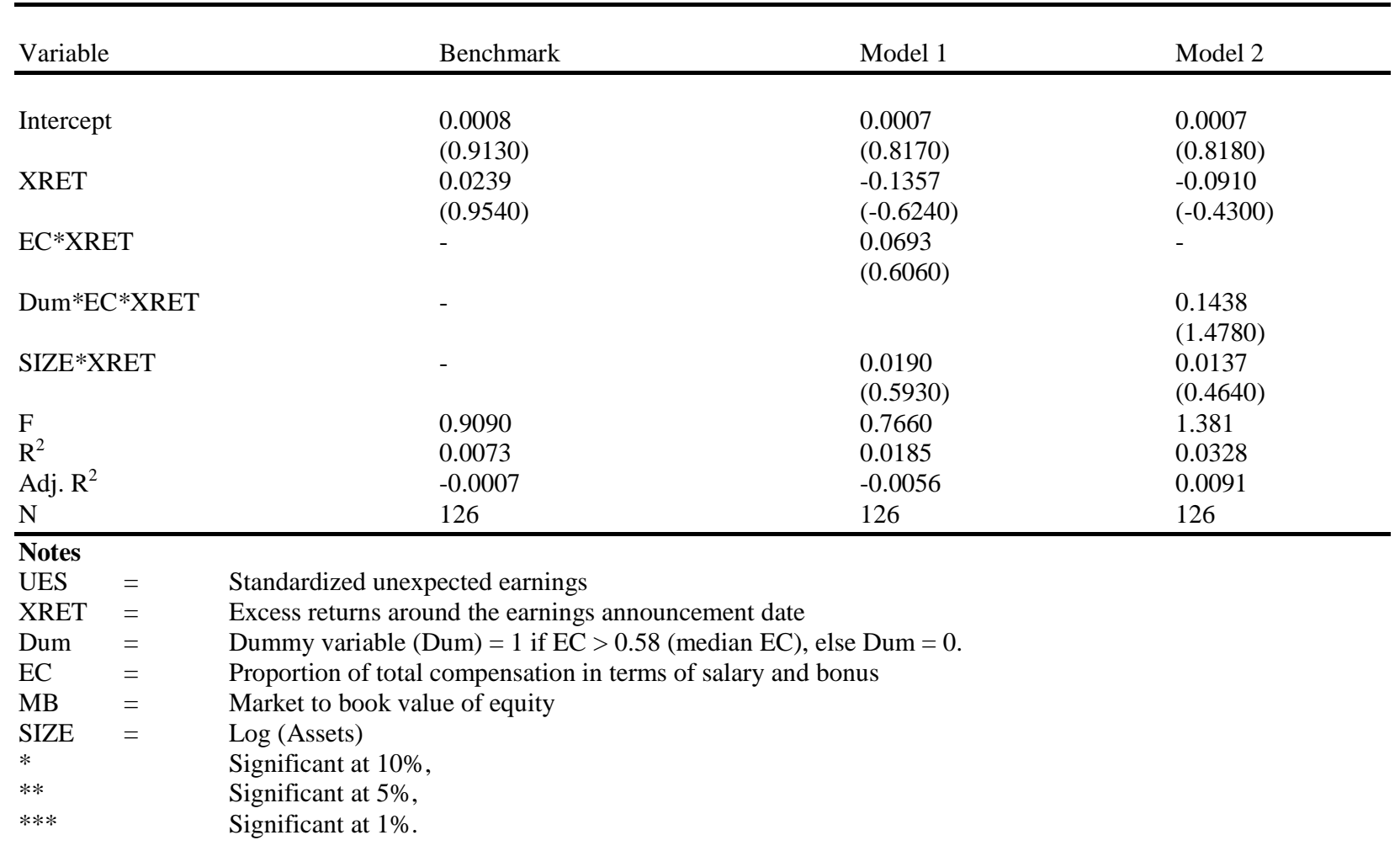

The Financial Accounting Standards Board in the United States has struggled with proper accounting for executive stock options for over ten years. Current accounting standards in the US allow flexibility in reporting. Firms can expense the fair value of the options or they can avoid most of the expense by using the intrinsic value approach. Our research indicates that executive stock options impact management behavior and therefore benefit 
the firm. We did not address the expensing vs. no expensing issue. However, in our opinion proper matching would suggest that the fair value of the options should be expensed in the period that managers adopt projects.

\section{Conclusion}

Prior literature suggests that earnings-based compensation tends to induce managers to invest in shorterterm projects. While there are many sources that collect data on CEO compensation, it is not practical to collect data on the project characteristics of each investment made by a large set of firms for an empirical study. Having developed a proxy for project life, we study the relation between management compensation and $E R C$. We find that firms that compensate their managers with greater proportionate short-term (earnings-based) compensation are also those with a lower $E R C$ or ones with a relatively short-lived asset mix. This result holds even after controlling for market to book value of equity and size of the firm.

\section{References}

1. Agrawal, A., and C. Knoeber, 1996, "Firm performance and mechanisms to control agency problems between managers and shareholders", Journal of Financial and Quantitative Analysis, 31, 3, 377-397.

2. Baber, W.R., S. Kang, and K. Kumar, 1998, "Accounting Earnings and Executive Compensation: The Role of Earnings Persistence", Journal of Accounting and Economics, 25, 169-193.

3. Beaver, W., R. Lambert, and S. Ryan, 1987, "The information content of security prices: A second look", Journal of Accounting and Economics, 9, 139-158.

4. Bowen, W, 1981, "How to regain our competitive edge", Fortune 103, March 9, 1981, 74-90.

5. Collins, D.W., and S.P. Kothari, 1989, "An analysis of intertemporal and cross-sectional determinants of earnings response coefficients", Journal of Accounting and Economics, 11, 143-182.

6. Collins, D.W., S.P. Kothari and J.D. Rayburn, 1987, "Firm size and the information content of prices with respect to earnings", Journal of Accounting and Economics, 9, 111-138.

7. Easton, P., and M. Zmijewski, 1989, "Cross-sectional variation in the stock market response to accounting earnings announcements", Journal of Accounting and Economics, 11, 117-141.

8. Goering, G., and T. Harikumar, 1999, "Investment decisions and managerial compensation design in the presence of product market rivalry", Managerial and Decision Economics, 20, 87-97.

9. Harikumar, T., and Charles I. Harter, 1995, "Earnings response coefficient and persistence: New evidence using Tobin's Q as a proxy for persistence", The Journal of Accounting, Auditing and Finance, Vol 10, 2, 401-420.

10. Hayes, R.H., and W.J. Abernathy, 1980, "Managing our way to economic decline", Harvard Business Review, July-August 1980, 67-77.

11. Kormendi, R., and R. Lipe, 1987, "Earnings innovations, earnings persistence and stock returns", Journal of Business, 60, 323-345.

12. Lehn,K., and A. Poulsen, (1989), "Free cash flow and stockholder gains in going private transactions", Journal of Finance, 44, 771-789.

13. Lewellen, W., C. Loderer, Claudio, and K. Martin, 1987, "Executive compensation and executive incentive problems: An empirical analysis", Journal of Accounting and Economics 9, 287-310.

14. Louis, A.M., 1984, "Business is bungling stock-based compensation", Fortune 106, July 23, 1984, 64-69.

15. Maddala, G.S., 1977, Introduction to Econometrics, Macmillan Publishing Company.

16. Miller, M.H., and K. Rock, 1985, "Dividend policy under asymmetric information", The Journal of Finance, 40, 1031-1051.

17. Narayanan, M.P., 1985, "Managerial Incentives for Short Term Results", Journal of Finance, 1469-1485.

18. Subramanyam, K.R., and J.J. Wild, 1996, Going Concern Status, Earnings Persistence, and Informativeness of Earnings, Contemporary Accounting Research, Vol 13, No. 2, 251-274.

19. Wahal, S., and John J. McConnell, 1997, “Do Institutional Investors Exacerbate Managerial Myopia?", Working paper, Purdue University.

20. Wooldridge, R., Competitive Decline and Corporate Restructuring: Is a Myopic Market to Blame? The New Corporate Finance Where Theory Meets Practice, Edited by Donald H. Chew, Jr, McGraw-Hill, Inc, 1993, 4151. 
$\underline{\text { Notes }}$ 